\title{
RECORDS OF THE HAWKSBILL TURTLE, ERETMOCHELYS IMBRICATA (LINNE), IN THE JAPAN SEA
}

$\operatorname{AUTHOR}(\mathrm{S}):$

Nishimura, Saburo; Yasuda, Toru

\section{CITATION:}

Nishimura, Saburo ...[et al]. RECORDS OF THE HAWKSBILL TURTLE, ERETMOCHELYS IMBRICATA (LINNE), IN THE JAPAN SEA. PUBLICATIONS OF THE SETO MARINE BIOLOGICAL LABORATORY 1967, 15(4): 297-302

\section{ISSUE DATE:}

$1967-12-20$

URL:

http://hdl.handle.net/2433/175474

RIGHT: 


\title{
RECORDS OF THE HAWKSBILL TURTLE, ERETMOCHELYS IMBRICATA (LINNÉ), IN THE JAPAN SEA ${ }^{1)}$
}

\author{
SAburo NISHIMURA \\ Seto Marine Biological Laboratory, Sirahama \\ and \\ TORU YASUDA \\ Fukui Prefectural Fisheries Experimental Station, Tsuruga \\ With 1 Text-figure
}

The hawksbill turtle, Eretmochelys imbricata (LINNÉ), inhabiting the tropicalsubtropical seas, is an occasional visitor to the Japanese waters. Most of its occurrences, however, have not been documented nor any effort has been made to compile the records made so far about the occurrences of this sea turtle; thus, its occurrence pattern in the Japanese waters are only vaguely known at present. The senior author, interested in the distribution and migration of sea turtles around the Japanese waters, especially in the Japan Sea, has made some effort, in cooperation with the junior author, to collect such records of the hawksbill turtle from the Japan Sea as many as possible.

So far 39 records have been gathered; some of them are picked up from the published documents, some are based on personal informations from the authors' acquaintances resident in various districts, and the rest are the records made by the authors themselves. All of these records are listed in Table 1, and the localities are shown on the map in Fig. 1.

The authors are much indebted to their cooperators who supplied them with informations; especially they are thankful to Mr. Ch. Sugrhara of Sakata City, Yamagata Prefecture, and Mr. T. Tsursumi of the Shimonoseki Aquarium, Shimonoseki City.

As seen in Fig. 1, the hawksbill is recorded from almost the entire west coasts of the Japanese Islands, from the Tsushima Islands in the south to the northwest district of Hokkaido in the north. Frequency of occurrence is not exactly known; but taking into account the fact that generally only a small portion of the captured or observed sea turtles are recorded or preserved, it may be concluded that the hawksbill

1) Contributions from the Seto Marine Biological Laboratory, No. 475.

Publ. Seto Mar. Biol. Lab., XV (4), 297-302, 1967. (Article 17) 
Table 1. Records of the hawksbill turtle in the Japan Sea, 1736-1967.

\begin{tabular}{|c|c|c|c|c|}
\hline $\begin{array}{l}\text { Record } \\
\text { no. }\end{array}$ & Locality & Date & Size* & Source \& remarks \\
\hline 1 & Hahoro, Hokkaido & Sept. 22, 1936 & BL $54 \mathrm{~cm}$ & KuRATA 1958 \\
\hline 2 & Aomori Bay & Late January, 1962 & CL $32 \mathrm{~cm}$ & \\
\hline 3 & Yamagata Pref. & Mar. 14,1883 & $\mathrm{PL} 18 \mathrm{~cm}$ & "Ryô-u Hakubuisu Zufu" $\dagger$ \\
\hline 4 & Yamagata Pref. & Jan. 19, 1889 & ? & $" \quad "$ \\
\hline 5 & Miyanoura, Sakata & November 1930 & CL $18 \mathrm{~cm}$ & $\begin{array}{l}\text { Deposited at H. ToмrTô's; } \\
\text { Sakata }\end{array}$ \\
\hline 6 & Jûrizuka, Sakata & Jan. 27, 1960 & CL $20 \mathrm{~cm}$ & $\begin{array}{l}\text { Deposited at Tosaka Primary } \\
\text { School, Sakata }\end{array}$ \\
\hline 7 & Miyanoura, Sakata & Feb. 11, 1961 & CL $23 \mathrm{~cm}$ & $\begin{array}{l}\text { Deposited at Miyanoura Pri- } \\
\text { mary School, Sakata }\end{array}$ \\
\hline 8 & Jûrizuka, Sakata & Jan. 31, 1962 & CL $8.5 \mathrm{~cm}$ & $\begin{array}{l}\text { Deposited at Tosaka Primary } \\
\text { School, Sakata }\end{array}$ \\
\hline 9 & Jârizuka, Sakata & December 1966 & CL $24 \mathrm{~cm}$ & $\begin{array}{l}\text { Deposited at T. HAsEGAWA's, } \\
\text { Sakata }\end{array}$ \\
\hline 10 & Yura, Tsuruoka & Around 1950 & $\mathrm{CL} 27 \mathrm{~cm}$ & $\begin{array}{l}\text { Deposited at Yura Primary } \\
\text { School, Tsuruoka }\end{array}$ \\
\hline 11 & $\begin{array}{l}\text { Gakkôchô-hama, } \\
\text { Niigata }\end{array}$ & Feb. 4, 1961 & CL $28 \mathrm{~cm}$ & $\begin{array}{l}\text { Deposited at Niigata High } \\
\text { School, Niigata }\end{array}$ \\
\hline 12 & $\begin{array}{l}\text { Aikawa, Sado } \\
\text { Island }\end{array}$ & 1736 & $?$ & “Sado Nendaiki”\& \\
\hline 13 & $\begin{array}{l}\text { Aikawa, Sado } \\
\text { Island }\end{array}$ & December 1787 & $?$ & ” \\
\hline 14 & $\begin{array}{l}\text { Aikawa, Sado } \\
\text { Island }\end{array}$ & 1791 & ? & $"$ \\
\hline 15 & $\begin{array}{l}\text { Shikabuse near Aikawa, } \\
\text { Sado Island }\end{array}$ & January 1808 & $?$ & \\
\hline 16 & $\begin{array}{l}\text { Furami near Aikawa, } \\
\text { Sado Island }\end{array}$ & January 1830 & ? & $"$ \\
\hline 17 & $\begin{array}{l}\text { Futami near Aikawa, } \\
\text { Sado Island }\end{array}$ & Feb. 10, 1961 & CL $30 \mathrm{~cm}$ & $\begin{array}{l}\text { Deposited at Aikawa High } \\
\text { School, Aikawa }\end{array}$ \\
\hline 18 & Nô, Niigata Pref. & Jan. 21, 1961 & CL $33 \mathrm{~cm}$ & Nishimura \& Mizusawa 1962 \\
\hline 19 & Nô, Niigata Pref. & Feb. 15,1965 & CL $25 \mathrm{~cm}$ & $\begin{array}{l}\text { Stranded dead. Deposited at } \\
\text { Nô Fisheries High School }\end{array}$ \\
\hline 20 & $\begin{array}{l}\text { Komatsu-shi, Ishikawa } \\
\text { Pref. }\end{array}$ & Feb. 7, 1952 & CI. $24 \mathrm{~cm}$ & Huzino 1952 \\
\hline 21 & Takanosu, Fukui Pref. & 1952 & CL $30 \mathrm{~cm}$ & $\begin{array}{l}\text { Deposited at Fukui Provincial } \\
\text { Museum }\end{array}$ \\
\hline 22 & $\begin{array}{l}\text { Matsubara coast, } \\
\text { Tsuruga }\end{array}$ & Jan. 20, 1965 & CL $29.8 \mathrm{~cm}$ & YASUDA (in press) \\
\hline 23 & Nyu Bay, Fukui Pref. & Jan. 23, 1967 & CI. $32.5 \mathrm{~cm}$ & YASUID (in press) \\
\hline 24 & $\begin{array}{l}\text { Near Obama, Fukui } \\
\text { Pref. }\end{array}$ & 1952 & CLL $30 \mathrm{~cm}$ & $\begin{array}{l}\text { Deposited at Obama Fisheries } \\
\text { High School }\end{array}$ \\
\hline 25 & Iwami, Tottori Pref. & Feb. 4, 1956 & CL $32 \mathrm{~cm}$ & KIYOSUYE 1956 \\
\hline 26 & Near Tottori-shi & ? & CL. $18 \mathrm{~cm}$ & $\begin{array}{l}\text { Deposited at Tottori Pref. } \\
\text { Sci. Museum }\end{array}$ \\
\hline 27 & Near Tottori-shi & Feb. 15,1960 & CL $25 \mathrm{~cm}$ & $" \quad " \quad$ \\
\hline 28 & $\begin{array}{l}\text { Ousaka coast, Tottori } \\
\text { Pref. }\end{array}$ & Jan. 15, 1956 & CL $42 \mathrm{~cm}$ & KIYOSUYe 1956 \\
\hline
\end{tabular}

* BL.-Body length; CL.-Carapace length; PL.-Plastron length.

† Old document "Illustrations of Natural Resources of Ryô-u District" (両羽博物図譜).

$\S$ Old document “Chronicle of Sado Island” (佐渡年代記). 
Table 1 (continued).

\begin{tabular}{|c|c|c|c|c|}
\hline $\begin{array}{l}\text { Record } \\
\text { no. }\end{array}$ & Locality & Date & Size & Source \& remarks \\
\hline 29 & Mita, Oki Islands & January 1956 & CL $16 \mathrm{~cm}$ & КАMITA 1965 \\
\hline 30 & Oki Islands (?) & $?$ & CL $54 \mathrm{~cm}$ & КАмітА 1962,1965 \\
\hline 31 & Off Hamada & June 28, 1962 & CL $40 \mathrm{~cm}$ & $\begin{array}{l}\text { Deposited at Hamada } \\
\text { Aquarium }\end{array}$ \\
\hline 32 & Hamada coast & $\begin{array}{l}\text { Occasionally in } \\
\text { summer }\end{array}$ & $\begin{array}{l}\text { Mostly less } \\
\text { than } 35 \mathrm{~cm}\end{array}$ & $\begin{array}{l}\text { Y. IMAOKA (in litt., May } 12 \text {, } \\
\text { 1967) }\end{array}$ \\
\hline 33 & $\begin{array}{l}\text { Off Takayama, } \\
\text { Yamaguchi Pref. }\end{array}$ & Jan. 5, 1958 & CL $37.5 \mathrm{~cm}$ & KАMITA 1962 \\
\hline 34 & $\begin{array}{l}\text { Wakyu, Hôhoku-cho, } \\
\text { Yamaguchi Pref. }\end{array}$ & October 1962 & $\begin{array}{l}\text { CL ca. } \\
\quad 40 \mathrm{~cm}\end{array}$ & $\begin{array}{l}\text { Shimonoseki Aquarium (in } \\
\text { litt., May } 31,1967 \text { ) }\end{array}$ \\
\hline 35 & $\begin{array}{l}\text { Yatama, Hôhoku-cho, } \\
\text { Yamaguchi Pref. }\end{array}$ & March 1964 & $\begin{array}{l}\text { CL ca. } \\
30 \mathrm{~cm}\end{array}$ & 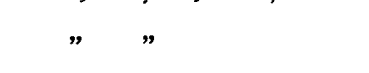 \\
\hline 36 & $\begin{array}{l}\text { Yutama, Toyoura-gun, } \\
\text { Yamaguchi Pref. }\end{array}$ & November 1962 & $\begin{array}{l}\mathrm{CL} \text { ca. } \\
45 \mathrm{~cm}\end{array}$ & $"$ \\
\hline 37 & $\begin{array}{l}\text { Yutama, Toyoura-gun, } \\
\text { Yamaguchi Pref. }\end{array}$ & September 1963 & $\begin{array}{l}\mathrm{CL} \text { ca. } \\
45 \mathrm{~cm}\end{array}$ & $"$ \\
\hline 38 & $\begin{array}{l}\text { Yasuoka-machi, } \\
\text { Shimonoseki }\end{array}$ & August 1964 & $\begin{array}{l}\text { CL ca. } \\
75 \mathrm{~cm}\end{array}$ & $"$ \\
\hline 39 & $\begin{array}{l}\text { Tsutsu, Tsushima } \\
\text { Islands }\end{array}$ & ? & $?$ & YAMAGUCHI 1966 \\
\hline
\end{tabular}

is by no means very rare along the west coasts of the Japanese Islands. This stands in contrast to the situation along the continental coast of the Japan Sea. So far as the authors are aware, no record has been made for the hawksbill along this coast: TERENTJEv \& Chernov (1949) mention a single record for each of the leatherback turtle Dermochelys coriacea (LINNÉ) and the red-brown loggerhead Caretta caretta (LINNÉ) from the coast of the Maritime Province, but nothing as to the occurrence of the hawksbill; according to Dor (1936a, 1936b), Shannon (1956), Takashima (1958) and others, three species of marine turtles, the leatherback, the (? red-brown) loggerhead and the green sea turtle Chelonia mydas (LinNÉ), have ever been captured in Korean waters, but no definite record of the hawksbill.

It is very noteworthy that the majority of the records from the west coasts of Japan with definite dates were made in winter months as shown below:

\section{HAWKSBILL OCCURRENCES IN THE JAPAN SEA IN RESPECTIVE MONTHS}

The figures in bold type indicate the number of records made in either the Yamaguchi-Shimane district of Honshu or the northwest Hokkaido, while the ordinary figures are the records made in the districts between those two localities respectively at the southern and northern extremities of the Japan Sea.

$\begin{array}{lrlr}\text { January } & 12 & \text { July } & 0 \\ \text { February } & 7 & \text { August } & \mathbf{1} \\ \text { March } & 1+\mathbf{1} & \text { September } & \mathbf{2} \\ \text { April } & 0 & \text { October } & \mathbf{1} \\ \text { May } & 0 & \text { November } & 1+\mathbf{1} \\ \text { June } & \mathbf{1} & \text { December } & 2\end{array}$


It is clearly shown that the records made in the warm season from June to October are concentrated in either the westernmost district of Honshu or the west coast of Hokkaido, while those from the districts between these extremities are all made in the cold season from November to March.

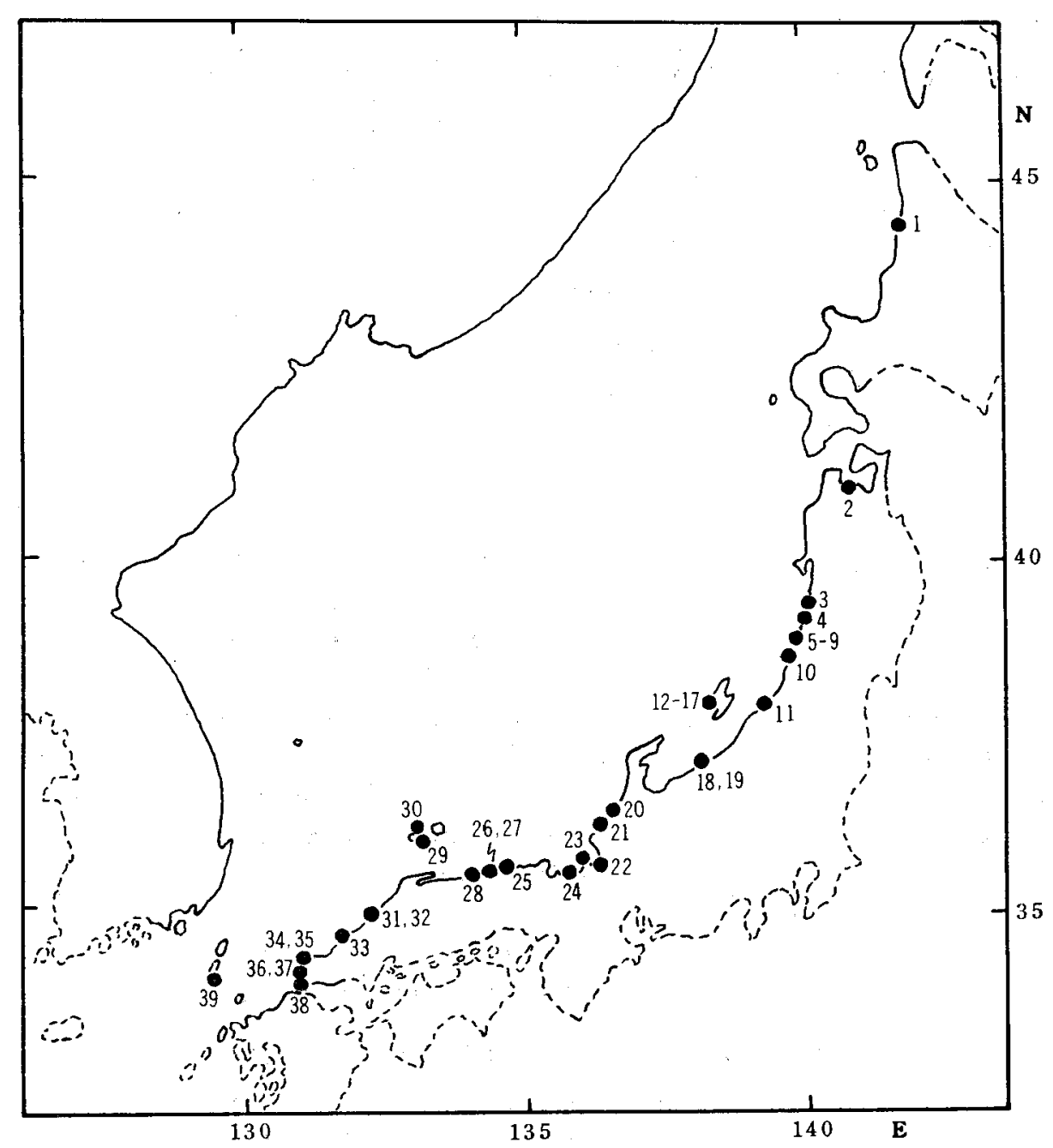

Fig. 1. Localities of the occurrences of the hawksbill turtle along the coasts surrounding the Japan Sea. A considerable number of occurrences have been recorded on the coasts of the Japanese Islands, while no definite record has ever been made on the continental coast. Numerals are the record numbers, for the details of which see Table 1.

Such a trend of occurrence, especially the concentrated occurrences in the cold season on the west coast of middle Honshu, may appear quite strange, since the migration of the hawksbill, a genuine tropical-subtropical animal, into the temperate 
region should be realized only in summer months when the surface water temperature is markedly raised. Similar trend is also known for the occurrence of the leatherback turtle in the Japan Sea (NIshimura 1964a, 1964b); it is as yet uncertain, however, whether or not the same mechanism as suggested for the migration or wandering of this athecate sea turtle (Nishimura 1964b) is applicable to the hawksbill, too.

The hawksbills so far caught in the Japan Sea were mostly young or immature individuals, generally smaller than $45 \mathrm{~cm}$ in carapace length (Table 1). The same may be said as to the individuals caught on the Pacific side of Japan. So far as the present authors are aware, mature hawksbills larger than $70 \mathrm{~cm}$ in carapace length (cf. Deraniyagala 1939, p. 205; Carr et al. 1966) are hardly captured in Japanthe capture of an individual about $75 \mathrm{~cm}$ in carapace length at Shimonoseki in August 1964 (no. 38 in Table 1) is truly an exceptional case. Thus, it seems very obvious that this sea turtle never breeds in the Japanese waters. It is supposed, though not substantiated as yet, that the natural habitat of those hawksbill turtles wandering to the Japanese waters is found in the tropical waters such as the South China Sea or the Philippine Sea respectively rich of coral reefs ${ }^{2}$. The record of the farthest travel of the hawksbill in the Japanese waters from the above-estimated natal seas may be that from off Nemuro, eastern Hokkaido, facing Nemuro or Notsuke Strait at the southern edge of the Okhotsk Sea (Sh. Noz.Awa in Okada 1930). It is supposed that this individual reached there after drifting through the Japan Sea and then the Okhotsk Sea passing through Soya Strait rather than that it reached there directly along the Pacific coasts of Honshu and Hokkaido Islands. It is an interesting fact that the young of this sea turtle apparently shows a marked tendency toward a long-distance dispersal much more than the adult which is believed rather strongly sedentary and limited in distribution (HoRnell 1927; INGLE \& SMITH 1949; NeILl 1958; Carr et al. 1966).

\section{REFERENGES}

Carr, A., Hirth, H. \& Ogren, L. 1966. The ecology and migrations of sea turtles 6. The hawksbill turtle in the Caribbean Sea. Am. Mus. Novit., no. 2248, pp. 1-29.

Deraniyagala, P. E. P. 1939. The tetrapod reptiles of Ceylon. Vol. 1-Testudinates and crocodilians. xxxii +412 pp., 34 pls. Colombo.

Dor, H. 1936a. [On a green sea turtle from the sea near Korea]. Shokubutsu oyobi Dôbutsu, vol. 4, pp. 797-798. (In Japanese).

_ 1936b. [On a leathery turtle from the sea near Korea]. J. Chosen Nat. Hist. Soc., no. 12, pp. 109-112. (In Japanese).

2) There are definite evidences for the fact that the hawksbill breeds in the Sulu Sea of the Philippines, around the Palau Islands of the Carolines and on the east coast of Malaya (TAYLOR 1920, 1921; Nakajima 1920; Okada 1932; Hayashi 193.5; Takahashi 1943; Hendrickson \& Alfred 1961; HENDRiGKson 1966; etc.) It is not yet confirmed, however, that the same species also breeds naturally in the waters around Formosa and the Ryukyu (Loochoo) Islands, though it seems fairly common there (cf. STEjneger 1907; OKada 1932; etc.); it is in fact stated that the hawksbills observed in those waters are all small individuals (OKADA 1932). 
Hendrickson, J. R. 1966. Observations on the fauna of Pulau Tioman and Pulau Tulai 5. The reptiles. Bull. Nat. Mus. Singapore, no. 34, pp. 53-71.

— \& Alfred, E. R. 1961. Nesting populations of sea turtles on the east coast of Malaya. Bull. Raffles Mus., Singapore, no. 26, pp. 190-196.

Hayashi, I. 1935. [Searching the hawksbill eggs in the South Sea]. Kagaku Chishiki, vol. 15, pp. 304-306. (In Japanese).

Hornell, J. 1927. The turtle fisheries of the Seychelles Islands. H. M. Stationery Office, London, 55 pp.

Huzino, T. 1952. Eretmochelys squamosa captured in Japan Sea. Saishu to Shiiku, vol. 14, pp. 266267. (In Japanese).

INGLE, R. M. \& Smrth, F. G. W. 1949. Sea turtles and the turtle industry of the West Indies, Florida and the Gulf of Mexico, with annotated bibliography. Spec. Publ. Mar. Lab., Univ. Miami, $107 \mathrm{pp}$.

Kamita, T. 1962. Visits by unusual aquatic animals to the sea coasts of San-in District, Japan Sea. San-in Bunka Kenkyu Kiyô, no. 2, pp. 1-35. (In Japanese).

- 1965. [Animals of the Oki Islands]. Matsue, Shimane Pref., 172 pp., 4 pls. (In Japanese).

Kiyosuye, T. 1956. [Eretmochelys imbricata captured on the coast of Tottori Prefecture]. Saishu to Shiiku, vol. 18, p. 377. (In Japanese).

Kurata, Y. 1958. [Notes on sea turtles]. Ushio, Tokyo, no. 19, pp. 9-10. (In Japanese).

NaKajima, K. 1920. [The hawksbill turtles of Palau Island]. Suisan Kenkyu Shi, vol. 15, pp. 145152. (In Japanese).

NeILL, W. L. 1958. The occurrence of amphibians and reptiles in saltwater areas, and a bibliography. Bull. Mar. Sci. Gulf \& Caribb., vol. 8, pp. 1-97.

Nishimura, S. 1964a. Records of occurrence of the leatherback turtles in adjacent waters to Japan. Physiol. \& Ecol., Kyoto, vol. 12, pp. 286-290. (In Japanese).

- 1964b. Considerations on the migration of the leatherback turtle, Dermochelys coriacea (L.), in the Japanese and adjacent waters. Publ. Seto Mar. Biol. Lab., vol. 12, pp. 61-73.

- \& Mizusawa, R. 1962. Exotic marine animals caught off Niigata Prefecture, Japan Sea, during the winter of 1960-61. Saishu to Shiiku, vol. 24, no. 3, pp. 32-35. (In Japanese).

OKada, Y. 1930. Notes on the herpetology of the Chichijima, one of the Bonin Islands. Bull. Biogeogr. Soc. Japan, vol. 1, pp. 187-194, 1 pl. (In Japanese).

- 1932. [Fisheries zoology]. Tokyo, vii+330 pp. (In Japanese).

Shannon, F. A. 1956. The reptiles and amphibians of Korea. Herpetologica, vol. 12, pp. 22-49.

Stejneger, L. 1907. Herpetology of Japan and adjacent territory. Bull. U. S. Nat. Mus., vol. 58, $\mathrm{xx}+577 \mathrm{pp}$.

TAkahashi, K. 1943. [Marine animal resources in the South Sea islands]. In Oshima, M. (ed.): Wonders of the South Sea (Tokyo), pp. 204-221. (In Japanese).

TAkashima, H. 1958. A synopsis of the reptiles of Japan. Misc. Rep. Yamashina's Inst. Ornith. \& Zool., no. 12, pp. 486-493. (In Japanese).

Taylor, E. H. 1920. Philippine turtles. Philippine J. Sci., vol. 16, pp. 111-144, 7 pls.

- 1921. Amphibians and turtles of the Philippine Islands. Bureau of Science Publ., Manila, no. 15,193 pp.

Terentjev, P. V. \& Chernov, S. A. 1949. [Key to the reptiles and amphibians]. Moscow, 339 pp. (In Russian).

Yamaguchi, T. 1966. Reptiles from Nagasaki Prefecture. Bull. Fac. Liberal Arts, Nagasaki Univ., Nat. Sci., vol. 6, pp. 19-36, 5 pls. (In Japanese).

YASUDA, T. Records of two occurrences of the hawksbill turtle, Eretmochelys imbricata (LinNaEus), in the vicinity of Tsuruga. Saishu to Shiiku, vol. 30 (in press). (In Japanese). 